\title{
一般 15
}

\section{CTで観察される腎錐体部の High Density Area}

背景

痛風患者の腎臓を単純へリカル CTで検査した 時に観察される陽性の所見には, (1) Calculus Density, (2) High Density Area (HDA) の2つが ある (Shimizu et al. J Rheum 36, 2009)。(1) は腎結 石とみなされている. (2) は腎錐体部に観察される 正常腎よりもややCT值に高い領域で，今までは臨 床的な意義も不明であり, 単に“High Density”と 呼ばれていて normal variation と考えられていた。

\section{目的}

痛風患者においてHDAを認めた症例の臨床的 特徵を調べ, HDAの意義について検討する。

\section{方 法}

痛風患者 274 例の初診時・治療開始前に単純へ リカルCTを行い, 腎錐体部にHDAが認められた 群と認められなかった群に分けて, クリアランス 検査（1時間法）から得られた腎機能, 尿酸動態お よび周辺疾患に関連するパラメータを比較した。

\section{結 果}

HDA は274例中 27 例 $(9.9 \%)$ に認められた. 比較したパラメータの中で, HDA (+) 群の血清 クレアチニン值の平均值 \pm 標準偏差は $1.02 \pm$ $0.10 \mathrm{mg} / \mathrm{dl}$ で, HDA ( - ) 群 (247例) の $0.89 \pm 0.14$ $\mathrm{mg} / \mathrm{dl}$ より有意に高く $(\mathrm{p}<0.0001), e G F R$, クレ アチニン・クリアランス $(\mathrm{Ccr})$ の平均值 \pm 標準 偏差はそれぞれ $63.13 \pm 9.00,4.44 \pm 1.07 \mathrm{ml} / \mathrm{min}$ で, HDA (-) 群の值 $(75.46 \pm 13.64,5.22 \pm 1.35 \mathrm{ml} /$
清水 徹 ${ }^{1)}$ 堀 浩 ${ }^{2}$

min）より低く（p<0.0001）, HDA $(+)$ 群の腎 機能は低下していることが判明した. HDA (+) 群の尿酸クリアランス（Cua）はHDA ( - ) 群 より高く $(\mathrm{p}=0.0038)$, 尿酸排泄量も多かった $(\mathrm{P}=0.0249)$ が，Cua/Ccrには有意差はなく，尿 酸排泄率の低下は腎機能の低下に伴うものと推定 された。両群の痛風発症年齢, 血清尿酸值, 尿 $\mathrm{pH}$ ，血圧，あるいは脂質代謝，糖代謝に関する パラメータには有意差はなかった。

\section{考察}

痛風と腎機能の関連に関しては既に多くの報告 があるが，高尿酸血症が腎機能障害をもたらすメ カニズム原因についてはまだ十分に解明されたと はいえない.今回の痛風患者における分析結果は, HDAが腎機能の低下に関与していることを示し ている.HDAが認められた症例を造影したとこ ろ, HDAの部位は腎錐体部に一致している。こ の領域には結石が形成される Bellini管や集合管が 集積しており, 尿の濃縮や酸性化が行われている. HDAの病理組織学的な本態が解明されれば, 腎 機能低下の機転が明らかになるのではないかと期 待される。

\section{結 論}

HDA は痛風患者の約 10\%に認められた. HDA は痛風に特有な所見とは限らないが，HDAを認 めた症例群の腎機能は明らかに低下していること から, 腎機能障害に関連するCT上の異常所見で あり, normal variation ではない.
1）みどりヶ丘病院リウマチ科(痛風外来)
Toru Shimizu
2)
同放射線科
Hiroshi Hori 